Article

\title{
Catalyzing Innovation: Governance Enablers of Nature-Based Solutions
}

\author{
Juliette G. C. Martin ${ }^{1, *}$, Anna Scolobig ${ }^{1,2}$, JoAnne Linnerooth-Bayer ${ }^{1}$, Wei Liu ${ }^{1}\left(\mathbb{D}\right.$ and Jörg Balsiger ${ }^{2} \mathbb{C}$ \\ 1 Risk and Resilience Program, International Institute for Applied Systems Analysis (IIASA), \\ 2361 Laxenburg, Austria; anna.scolobig@unige.ch (A.S.); bayer@iiasa.ac.at (J.L.-B.); liuw@iiasa.ac.at (W.L.) \\ 2 Environmental Governance and Territorial Development Hub/Institute (GEDT), University of Geneva, \\ CH-1205 Geneva, Switzerland; joerg.balsiger@unige.ch \\ * Correspondence: martinj@iiasa.ac.at
}

Citation: Martin, J.G.C.; Scolobig, A.; Linnerooth-Bayer, J.; Liu, W.; Balsiger J. Catalyzing Innovation: Governance Enablers of Nature-Based Solutions. Sustainability 2021, 13, 1971. https:// doi.org/10.3390/su13041971

Academic Editors: Gerd Lupp and Aude Zingraff-Hamed

Received: 4 December 2020

Accepted: 7 February 2021

Published: 11 February 2021

Publisher's Note: MDPI stays neutral with regard to jurisdictional claims in published maps and institutional affiliations.

Copyright: (c) 2021 by the authors. Licensee MDPI, Basel, Switzerland. This article is an open access article distributed under the terms and conditions of the Creative Commons Attribution (CC BY) license (https:// creativecommons.org/licenses/by/ $4.0 /)$.

\begin{abstract}
There is growing recognition that using the properties of nature through nature-based solutions (NBS) can help to provide viable and cost-effective solutions to a wide range of societal challenges, including disaster risk reduction (DRR). However, NBS realization depends critically on the governance framework that enables the NBS policy process. Drawing from three case studies in Nocera Inferiore (Italy), Munich (Germany), and Wolong (China), we identify key governance enablers-the contextual preconditions, policy processes, and institutions-that proved essential for NBS initiation, planning, design, and implementation. In the three cases, interviews confirm the success of the NBS measures and their benefits in terms not only of DRR but of multiple ecological and social-economic co-benefits. Results highlight critical governance enablers of NBS, including: polycentric governance (novel arrangements in the public administration that involved multiple institutional scales and/or sectors); co-design (innovative stakeholder participatory processes that influenced the final NBS); pro-NBS interest and coalition groups (organized pressure groups that advocated for an NBS); and financial incentives (financing community-based implementation and monitoring of NBS). Findings show that the transition to NBS can contribute to multiple global agendas, including DRR, climate change adaptation, and sustainable development.
\end{abstract}

Keywords: nature-based solutions; NBS; governance; disaster risk reduction; DRR; enabler; landslide; flood

\section{Introduction}

Nature-based solutions (NBS) are defined by the European Commission as "inspired and supported by nature which are cost-effective, simultaneously provide environmental, social and economic benefits and help build resilience" [1]. NBS seek to provide society with multiple co-benefits, such as ecological resilience, economic growth, and health [2]. They are increasingly being adopted as complements or alternatives to traditional "hard" or "grey" infrastructure solutions that exclusively involve structural features [3-5]. Until recently, the term NBS was virtually absent from political or public agendas in the disaster risk management sector, while sister concepts such as ecosystem-based disaster risk reduction or ecosystem-based adaptation were featured extensively [6]. This is rapidly changing at all scales, and particularly at international fora, where they have emerged, for instance, at the 25th Conference of the Parties (COP) discussions and expected COP 26 negotiations. At least $66 \%$ of the Paris Agreement signatories explicitly refer to NBS in some form to help achieve their climate change mitigation and/or adaptation goals [7]. Thus, the ambition to mainstream NBS into global agendas to deliver on the Sustainable Development Goals and other post-2015 targets is growing [8].

This study focuses on NBS for adapting to extreme weather events in mountainous areas, where landslides, rockfalls, floods, and droughts impose high risks on human lives as well as on infrastructure, goods, and assets [9]. The cost of disaster risk reduction (DRR) 
measures and emergency costs in European alpine countries has been estimated to range between 44 and 216 EUR/year per capita [10]. Costs are further exacerbated by the rising intensity and frequency of natural hazards associated with a changing climate [11,12]. Furthermore, while, to date, most NBS research has focused on urban environments (e.g., [2,13-16]), there is great potential for NBS to reduce hydro-meteorological risks in rural mountainous areas. Examples of NBS that aim to minimize risks from extreme weather events in mountain areas include vegetating slopes to reduce landslide risk [17], buffer strips and buffering zones to reduce erosion and contain flood water [18], widening riverbeds to reduce flood risks [19], and the afforestation of slopes ("protection forests") to mitigate avalanche and rockfall risks [20]. NBS are thus regaining attention as promising strategies for reducing disaster risk [16,21].

Despite NBS' recent rise to the limelight, many European and national NBS policies are still grounded in voluntary measures, such as encouragements to create green spaces, resulting in fragmented applications of NBS [22]. Therefore, understanding the governance enablers that have characterized the successful realization of NBS is essential for identifying relevant policy instruments and incentive mechanisms that can better enable NBS implementation and upscaling, especially for DRR. Despite this, research on the enablers of and opportunities for NBS implementation is sparse, with studies and reports primarily focusing on urban NBS (e.g., [2,23,24]), their barriers (e.g., [25]), or their potential for climate change adaptation (e.g., [26,27]).

Through an online survey, Bernardi et al. [28] identified major NBS drivers including policy drivers (e.g., policies to support collaboration and co-design for local empowerment), market drivers (e.g., incentives and other ways to monetize NBS), and communication drivers (e.g., cross-sectional networking). In a case study review drawing overarching lessons on NBS implementation, Frantzeskaki [29] highlights the importance of an inclusive and collaborative governance approach for co-creating NBS in urban environments. This is also emphasized by Schmalzbauer [25], who found that citizen involvement, political support, social inclusion, public acceptance, financial support, monitoring and evaluation, and upscaling represented key success factors for effectively co-creating NBS for urban regeneration. Likewise, Kabisch et al.'s findings [13] show that NBS for climate change mitigation and adaptation in urban areas are driven by valorizing and exploiting existing tacit and expert knowledge, as well as establishing and practicing collaborative governance approaches. Davies and Lafortezza [5] argue that breaking away from the mold of historic grey infrastructure approaches constitutes the most significant hurdle to the uptake of NBS. To overcome this, four transition paths are proposed: education of infrastructure professionals on NBS, institutional and cultural reform by changing the "grey over green" paradigm, community empowerment, and increased public-private partnerships for procuring NBS. Finally, a review by Sarabi et al. [23] demonstrated that open innovation and experimentation, partnerships among stakeholders, effective monitoring and valuation systems, and education and training are amongst the most important NBS enablers in urban settings.

The intent of this study is to build on this existing body of knowledge by identifying the institutional, legal, social, and economic factors - in short, governance frameworks-for initiating, planning, designing, and implementing NBS in three selected case studies:

- $\quad$ Flood risk on the alpine Isar River in Munich, Germany (Isar case);

- $\quad$ Flood and landslide risk in Wolong National Nature Reserve, China (Wolong case); and

- $\quad$ Landslide risk in Nocera Inferiore, Italy (Nocera case).

The case studies were chosen because of their widely acknowledged success in realizing NBS for risk management [30-40]. While the focus is on NBS enablers, we recognize the importance of also considering NBS barriers, which were however not unsurmountable in the selected cases, rather representing challenges and limitations. For each case study, we explore the pre-existing conditions and new and potentially innovative governance processes, conditions, and other factors that helped to enable the realization of the respective NBS. We highlight those factors that were novel or drove innovation-that is, spearheaded 
new or improved ideas, practices, behaviors, or knowledge in the NBS process and/or outcome [41,42]. We also report on how stakeholders view the implemented NBS in terms of their main benefits and co-benefits.

\section{Materials and Methods}

\subsection{Concept and Methods}

There is an ongoing debate on how nature-based solutions (NBS) are defined and what they consist of $[43,44]$. In this study, the concept of NBS is based on the European Commission's definition of NBS ("solutions that are inspired and supported by nature" which "must benefit biodiversity") [1]. As shown in Figure 1, this definition implies a continuum of grey-green infrastructure elements that define NBS. Green and grey infrastructure elements are often combined to form hybrids, as is the case with many existing structural measures that are subsequently greened (e.g., rooftop gardens) [45]. Accordingly, NBS include different degrees of engineering-from grey-green solutions, which incorporate green elements into grey infrastructure, to prompted recovery, where natural processes are restored. Hybrids, which combine both natural and manmade infrastructure elements, are thus encompassed in this definition (Figure 1).

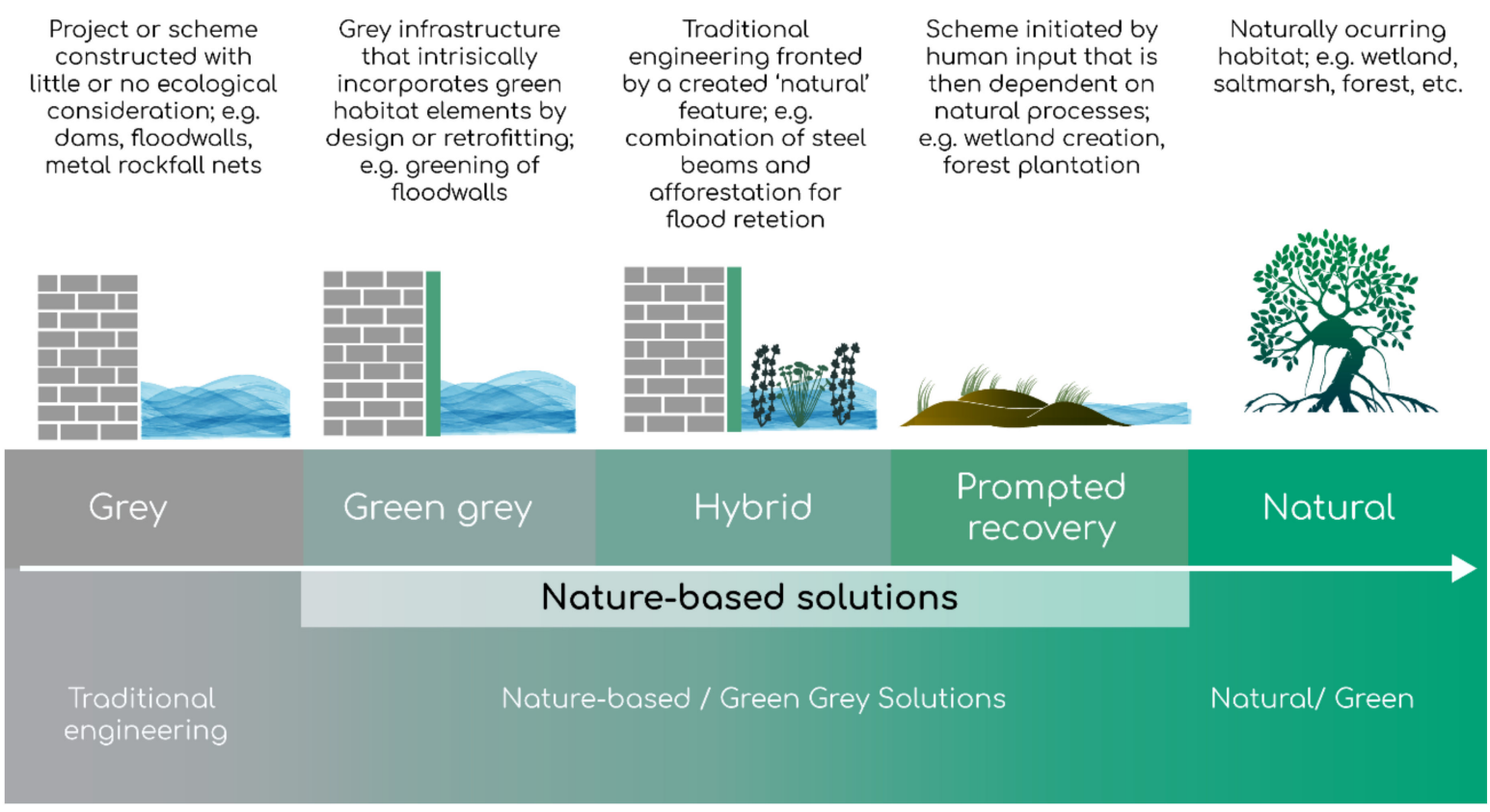

Figure 1. The grey-green continuum of infrastructure approaches (Adapted from [45]; Sources [46]).

For our purposes, governance was defined as all formal and informal processes and conditions through which society or groups within it, including government, businesses, civil society organizations, among others, organize to make policy decisions and realize societal aims (adapted from $[47,48]$ ). Governance enablers are hence defined as those processes, conditions, or factors that play a positive role in how government, market, and civil society actors or stakeholders organize to make policy decisions on NBS at different stages of their realization, including:

1. Enablers as preconditions that are in place before the project is initiated;

2. Enablers that emerge during the project initiation, planning, and design; and

3. Enablers that emerged during the project implementation (Figure 2). 


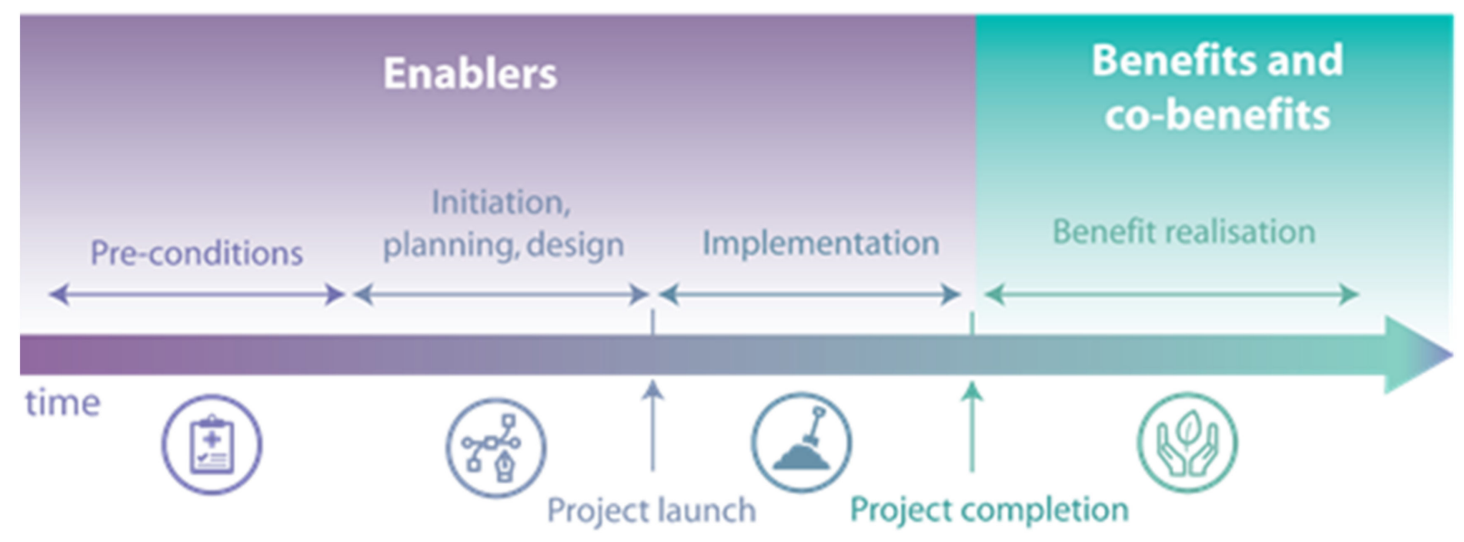

Figure 2. Enablers throughout the nature-based solution realization stages [49].

The analysis focused on governance enablers in six categories: political, socio-cultural, legal, financial, human resources, and institutional, although, depending on the casespecific findings, enabler categories were merged where appropriate. This typology was developed based on ideas that emerged from the transcribed text, using interpretative procedures of Grounded Theory [50], and refined using existing work on governance and/or NBS indicators $[13,24,25,27,51,52]$. These categories proved useful in identifying the processes, conditions, and factors that supported the actor networks as they organized and deliberated throughout the NBS policy process. Those enablers that were not processoriented, such as bio-physical and environmental factors, are excluded from the analysis. The identification of benefits and co-benefits was based on the ambits developed by Autuori et al. [53].

To identify governance enablers for the realization of each of the three NBS, peerreviewed and grey literature (including publications, reports, media, web sites, legal documents, etc.) were consulted for establishing the background and context (including historical facts, relevant legislations, political background, and technical information on NBS) of each case. Targeted open-ended interviews using the same interview protocol (Appendix A) were undertaken with stakeholders to extract NBS enablers. A total of 21 interviews were conducted for the Nocera case in 2018, 15 for the Isar case in 2018, and 11 for the Wolong case in 2019. The Wolong and Nocera cases build on interview data that were gathered in previous research projects ("Effects of Cross-Boundary Processes on Human-Nature Dynamics in Wolong Nature Reserve for Giant Pandas" [54] and "SafeLand" [55], respectively). Further information on interviewees and interviews can be found in Appendix B. Interviewees were identified through expert consultation and snowball sampling. Interview transcripts were analyzed using a quantitative content analysis to assign codes (to ideas that emerged from the transcribed text using Grounded Theory [50], creating the basis of the enabler typology used in this study). Appendix C provides an example of the iterative process through which codes were extracted from interviews. Interviews and quotes were translated by the authors. As NBS enablers were elicited from interviews, they are not meant to represent an exhaustive or objective list, but rather to provide a subjective assessment based on an inclusive sampling of stakeholders. Likewise, while each of the three cases has been acclaimed as a success, we recognize that "success" is subjective, depending on "to whom" or "for whom". For this reason, we report only on how stakeholders view the implemented NBS in terms of their main benefits and co-benefits.

Recognizing that results from three disparate cases cannot be universally generalized across other NBS cases, the aim is to provide insights into governance institutions, procedures, and other factors that have enabled NBS in three countries. Case studies were thus used to draw analytical conclusions and cross-case insights that inform existing theory and evidence on NBS governance enablers [56]. Due to the uniqueness of each case, results are 
reported by case study, rather than by enabler category. Further information on the study methods and materials can be found in the Supplementary Materials.

\subsection{Case Study Sites}

In addition to their previously mentioned recognition in implementing NBS for DRR, the Isar, Wolong, and Nocera cases were chosen based on their geographic spread, diverse governance structures, mountainous character (situated in the alpine foreland, Min Shan mountains, and Lattari mountains, respectively), and their diversity in hazard exposure (floods, combined landslides and floods, and landslides, respectively). The main characteristics of each case are summarized in Table 1.

Table 1. Selected characteristics of the Isar, Wolong, and Nocera cases.

\begin{tabular}{|c|c|c|c|}
\hline & $\begin{array}{l}\text { Isar-Plan } \\
(2000-2011)\end{array}$ & $\begin{array}{l}\text { Wolong National Nature } \\
\text { Reserve (2000-Present) }\end{array}$ & $\begin{array}{l}\text { Nocera Inferiore } \\
\quad(2015-2019)\end{array}$ \\
\hline Location & Munich, Germany & Sichuan Province, China & Campania, Italy \\
\hline $\begin{array}{l}\text { Main reason for NBS } \\
\text { implementation }\end{array}$ & Flood protection & $\begin{array}{l}\text { Flood and landslide } \\
\text { protection }\end{array}$ & Landslide protection \\
\hline Main co-benefits & $\begin{array}{l}\text { Ecological restoration, } \\
\text { recreation }\end{array}$ & $\begin{array}{l}\text { Biodiversity conservation, } \\
\text { socioeconomic development }\end{array}$ & $\begin{array}{l}\text { Recreation, environmental } \\
\text { awareness }\end{array}$ \\
\hline $\begin{array}{l}\text { Approximate } \\
\text { cost }\end{array}$ & EUR 35 million & EUR 1 million/year (2019) & EUR 637,000 \\
\hline Main implemented NBS & Restoration of riverbed & $\begin{array}{l}\text { Forest conservation and } \\
\text { afforestation }\end{array}$ & $\begin{array}{l}\text { Natural remediation measures } \\
\text { (e.g., gabions) }\end{array}$ \\
\hline
\end{tabular}

\subsubsection{Isar Case}

Munich's Isar River, which rises in the Austrian Alps, is characterized by extreme hydrologic regimes dominated by orographic rainfall [57]. The Isar has been described as a "lifeline" for Munich's cultural heritage, identity, and urban recreation [58,59]. Only two decades ago, however, the Isar was contained within a narrow concrete "corset," having been channelized in the 18th century to facilitate its hydropower exploitation. This case study reports on the restoration of the Isar in 2000-2011 (referred to as the Isar-Plan project), during which an 8-km-long stretch of the Isar in Munich was "re-naturalized" using a hybrid of NBS and grey measures [60]. The measures implemented included the widening and deepening of the riverbed, the addition of natural material to reduce the river's flow speed and enhance the quality and connectivity of fish habitats, and the reinforcement of existing levees with underground steel beams to preserve vegetation and fulfil the Munich Water Agency's goal of protecting Munich from extreme floods [30]. The Isar-Plan was jointly implemented by the State of Bavaria and the City of Munich and is widely acclaimed for having successfully turned a formerly concrete and unsafe riverbank into a green/blue recreational space, now an indispensable emblem of the city $[31,34,61]$. The Munich Water Agency and City of Munich were in control of a budget that, although earmarked primarily for mitigating flood risk, could be allocated for the Isar NBS project, given the Water Agency's broad mandate that included not only flood risk mitigation, but also social wellbeing and ecological objectives.

\subsubsection{Wolong Case}

Over the past two decades, China has implemented some of the world's largest NBS programs, including the Natural Forest Conservation Program (NFCP), to tackle its increasing disaster risk, environmental, and related socioeconomic challenges. The implementation of NFCP in Wolong, a flagship protected area located in a global hotspot region of disasters [40] and biodiversity (particularly giant pandas) [62], is a renowned local success [38-40]. The NFCP aimed to conserve natural forests mainly through a nationwide logging ban and large-scale afforestation and reforestation policy that involved financial 
incentives for community-based monitoring of illegal logging. This study reports on the implementation of a nature-based solution to flooding and landslides that was carried out in upstream tributaries of the Yangtze River in the Wolong Nature Reserve (WNR) in the Western Sichuan mountains. The State Forestry Administration (SFA), through its Center for Natural Forestry Conservation and Management, provided the direct funding needed for the NBS implemented through the NFCP. A key characteristic of this project was the introduction of a forest management concession contractual system - the "carrot and stick" approach. The contract essentially rewarded households for monitoring illegal logging in designated areas (carrots) and sanctioned households (either singularly or collectively) if illegal logging took place (sticks). The analysis focuses on the period 1999-2001, when the NBS program was initiated, planned, designed, and implemented.

\subsubsection{Nocera Case}

In 2005, a severe landslide was triggered by heavy rainfall on the northern slope of Monte Sant'Angelo di Cava, located upslope of the town of Nocera Inferiore. After the event, the Regional Civil Protection set up an Emergency Commissariat, which presented a proposal for new structural protection works for the most endangered areas in Nocera Inferiore. However, the project was rejected by the municipal council in 2008 . The main reason was that the project primarily included structural or "grey" measures, whereas residents had prioritized nature-based solutions and other measures with a low environmental impact. In the wake of this rejection, two Emergency Commissioners were appointed, and a EUR 7.2 million budget was earmarked for a risk mitigation plan. This stalemate signaled the need for a more inclusive and transparent landslide policy and decision-making processes. The municipal authorities were hence keen to involve the residents of Nocera Inferiore in the preparation of a new landslide risk mitigation plan. The entry point to public participation was provided by a European Commission (EC)-funded research project involving a two-year co-design process structured as a series of workshops involving a group of selected residents, experts, and several parallel activities open to the public [37,63]. This eventually led to the implementation of NBS for reducing landslide risk to the town in 2018-2019 [32]. The implemented NBS included maintenance and remediation of the mountain slope, channel lining, and vegetated and stone gabions aimed at reducing erosion due to frequent rainfall events. The NBS are part of a more comprehensive and hybrid plan that includes, for example, complementary grey infrastructure, the improvement of walking paths, and improved management of public and private forests.

\section{Results}

\subsection{Governance Enablers}

\subsubsection{Isar Case}

Based on the 15 stakeholder interviews and narratives, the Isar-Plan was, without exception, considered a success in terms of its ecological, social, and flood-reduction benefits, as well as its inclusive process of stakeholder involvement. Although the Isar-Plan was initially conceived as a flood protection project, its recreational and social benefits were voiced most prevalently in stakeholder responses. This is noteworthy, especially as social value, particularly cultural heritage, intrinsic, and spiritual values, is difficult to assess in formal cost-benefit analyses and thus less represented in NBS research [64].

As shown in Table 2, the realization of the Isar-Plan according to the interviewees was enabled by multiple prior conditions that were in place (or put in place) before the plan was initiated and by the governance and other factors that emerged during its over two-decade-long initiation, planning, design, and implementation. 
Table 2. Enablers of the Isar-Plan in the view of the interviewed stakeholders.

Enablers as Precondition

Enablers during Initiation, Planning, Design, and Implementation

\begin{tabular}{|c|c|c|c|}
\hline \multirow[b]{2}{*}{ Socio-cultural } & \multirow[t]{2}{*}{ Enablers as Preconditions } & \multicolumn{2}{|c|}{ Enablers during Initiation, Planning, Design, and Implementation } \\
\hline & & & \\
\hline $\begin{array}{l}\text { Environmental } \\
\text { awareness }\end{array}$ & $\begin{array}{c}\text { Green movements were on the rise and "en vogue." The City's mayor was from } \\
\text { the Green Party }\end{array}$ & $\begin{array}{l}\text { Risk awareness raised by } \\
\text { extreme events }\end{array}$ & $\begin{array}{l}\text { Large floods occurring during the project construction (in } 1999 \text { and 2005) } \\
\text { helped increase the awareness of the NBS' potential benefits and renew funding }\end{array}$ \\
\hline $\begin{array}{l}\text { Interest/pressure } \\
\text { groups }\end{array}$ & $\begin{array}{l}\text { The Mühltal group, consisting of environmental stakeholders, had been formed } \\
\text { to advocate increased water for the Isar in the early 1990s }\end{array}$ & Interest/pressure groups & $\begin{array}{l}\text { The former Mühltal group formed the Isar Alliance in 1993, which rallied } \\
\text { environmental NGOs in support of the Isar-Plan }\end{array}$ \\
\hline \multirow[t]{2}{*}{$\begin{array}{l}\text { Risk awareness raised } \\
\text { by model }\end{array}$} & $\begin{array}{l}\text { Through a hydrological model, the Munich Water Agency realized that flood } \\
\text { protection of Munich was insufficient in the case of a 100-year flood event }\end{array}$ & Stakeholder engagement & $\begin{array}{l}\text { Stakeholders were consulted and engaged throughout the stages of the } \\
\text { Isar-Plan and were able to co-design the NBS measures }\end{array}$ \\
\hline & & $\begin{array}{l}\text { Trust relationship } \\
\text { between stakeholders }\end{array}$ & $\begin{array}{c}\text { The long-lasting collaboration between stakeholders (over } 15 \text { years) with few } \\
\text { unresolved conflicts resulted in a trust relationship }\end{array}$ \\
\hline \multicolumn{4}{|l|}{$\begin{array}{l}\text { Legal/institutional/ } \\
\text { political }\end{array}$} \\
\hline $\begin{array}{l}\text { Favorable public } \\
\text { property rights }\end{array}$ & $\begin{array}{l}\text { The land along the eastern riverbank of the Isar, where the river basin was to be } \\
\text { widened, was owned by the City of Munich. }\end{array}$ & Local champion & The Mayor of Munich was in favor of the project. \\
\hline Mandate and authority & $\begin{array}{c}\text { The Munich Water Agency and the City of Munich both had the mandate to } \\
\text { protect the city from floods }\end{array}$ & Clearly defined goals & $\begin{array}{c}\text { Throughout the Isar-Plan, the three goals of the project (recreation, flood } \\
\text { protection, ecology) prevailed and guided the Water Agency and } \\
\text { city representatives }\end{array}$ \\
\hline \multirow[t]{3}{*}{ Existing legal basis } & $\begin{array}{l}\text { Existing legal documents, including the Bavarian Constitution and German } \\
\text { Federal Water Act, contained paragraphs favoring the restoration of rivers }\end{array}$ & Common vision & $\begin{array}{l}\text { All stakeholders were in favor of the Isar-Plan and associated themselves with } \\
\text { at least one of its three goals (recreation, flood protection, ecology) }\end{array}$ \\
\hline & & Cross-scale collaboration & $\begin{array}{l}\text { The Isar-Plan Working Group was created by the Munich Water Agency and } \\
\text { included representatives from the State of Bavaria and the City of Munich }\end{array}$ \\
\hline & & $\begin{array}{l}\text { Cross-sectoral } \\
\text { collaboration }\end{array}$ & $\begin{array}{l}\text { The Isar-Plan Working Group brought together members from public } \\
\text { institutions and NGOs, ranging from city planning to fisheries }\end{array}$ \\
\hline \multicolumn{4}{|l|}{ Human resources } \\
\hline $\begin{array}{l}\text { Expert knowledge and } \\
\text { expertise }\end{array}$ & $\begin{array}{l}\text { Both the City of Munich (the Health and Environment, Construction, and } \\
\text { Planning Divisions) and the Bavarian Water Agency had relevant experience } \\
\text { and expertise in landscape planning and flood control, respectively }\end{array}$ & $\begin{array}{l}\text { Communication strategy } \\
\text { and platforms }\end{array}$ & $\begin{array}{l}\text { An extensive communication strategy (led by the Water Agency) informed } \\
\text { stakeholders about what was to be implemented and where }\end{array}$ \\
\hline $\begin{array}{l}\text { Previous risk control } \\
\quad \text { (residual risk) }\end{array}$ & $\begin{array}{l}\text { Thanks to the construction of the upstream Sylvenstein reservoir in 1959, flood } \\
\text { risk had been already reduced, leaving only residual risk (losses in the event of a } \\
\text { 100-year flood) to be addressed by the Isar-Plan }\end{array}$ & & \\
\hline \multicolumn{4}{|l|}{ Financial resources } \\
\hline Available funds & A budget had been earmarked to increase flood protection. & & \\
\hline
\end{tabular}


Results show the importance of prior conditions that helped pave the way for the Isar-Plan. Perhaps the most essential precondition again according to interviewees was the availability of funds from the City of Munich and the Bavarian state authorities. Although earmarked for flood protection, the available funds were sufficient to expand the Water Agency's agenda beyond reinforcing the protection barriers (grey infrastructure) to include the ecological and recreational benefits of a re-naturalized river. In addition to available funds, a critical battle had already been waged. Environmental groups had succeeded in claiming increased residual water essential for the Isar-Plan from the Mühltal hydropower plant, whose concession had expired. These same stakeholders later formed an influential coalition of environmental groups (the Isar Alliance) that advocated for, and ultimately co-designed, the NBS. One member of this coalition, the Fisheries Association, viewed the Alliance's advocacy as a major factor in spiraling the Isar-Plan onto the political agenda:

The members of the Isar Alliance stood up for the Isar restoration. This was picked up by the politicians. Munich's mayor at the time then also gave his support (Interviewee \#9).

Resident groups, several of which pre-date the Isar-Plan initiation, exploited the Isar Alliance activities to promote their agenda-public access to an ecologically restored river [65]. Additionally, although Munich had not experienced major floods at that time (Sartori, 2010), a hydrological model relied on by Munich's Water Agency showed that the city was at risk from a 100-year flood [60]. This model opened a crucial window of opportunity for already existing environmental groups or sympathetic state authorities-along with the expert community - who then advocated for a hybrid (blue-green-grey) solution. Furthermore, two important legal documents served as a legal basis for introducing the Isar-Plan: the Bavarian Constitution and Nature Conservation Act [66,67]. These served as powerful instruments to bolster the Isar-Plan advocates. In the words of a member of the Isar Alliance:

What we did was backed up by the law. ... even if someone in the administration was not happy about [the Isar-Plan], they could not say anything against it (Interviewee \#4).

Once the idea of the Isar-Plan was launched in 1987 at an expert colloquium organized by the City Council to discuss the different options for the future Isar [68], several factors proved key for enabling its subsequent planning, design, and implementation. The Munich Water Agency and representatives from the Munich municipality were in the vanguard of participatory co-design by actively engaging environmental NGOs, residents, and other stakeholders in its planning $[35,69]$. While the importance of stakeholder engagement in NBS design and implementation is increasingly recognized (e.g., [4,70]), it was much less common when the Isar-Plan was launched. As expressed by a former employee of the Munich Water Agency who worked on the Isar-Plan:

We did not have clear rules or guidelines for stakeholder involvement-but we had to keep everyone informed (... ). I think it was very important for the success of the project that participation and stakeholder involvement were continuously established or, in other words, that a change in culture was developed. In the end this is the only way to realize such large projects (Interviewee \#10).

The Isar-Plan was also innovative in another aspect of its governance model. The water authorities of the State of Bavaria and the City of Munich collaborated in advocating a far broader vision for the Isar than their customary focus on grey infrastructure for flood protection. This collaboration was initiated by ecologically committed staff members who formed, for the first time, a multidisciplinary and multi-agency working group. The vision of an NBS for Isar flood protection as held by motivated administrative staff was a key driver for the innovative institutional approach, which could potentially transform flood risk management in Munich and serve as a model for other NBS projects. The multiscale and cross-sectoral collaboration-breaking the silos of water and urban planningwas unprecedented for projects of this magnitude. The collaboration across different jurisdictional scales and sectors represents key characteristics of polycentric governance, which denotes a system in which decisions are taken at different jurisdictional levels and 
scales (e.g., national, regional, global) through sometimes formally independent decision centers [71-74]. This resulted in a relationship of trust among stakeholders who sometimes had conflicting values and interests. As noted by an employee of the Munich Water Agency:

The different solutions were always weighed up. The Isar-Plan Working Group served to discuss challenges amongst various experts (... ). We said we will develop what we want to build in Munich together. This was the first time that such a Working Group had been created (Interviewee \#2).

The Isar-Plan process offers many lessons for enabling NBS. Not least, it reinforces the observation that the implemented natural measures were only viable because they "piggy-backed" on a grey solution. At the core of the Isar-Plan-and the mandate of the funding authorities-was the reinforcement of the existing flood protection with steel beams that were hidden under tree-lined levies. Nevertheless, it is remarkable that the reinforcement of the structural (grey) flood protection was accompanied by cross-scale measures to transform the Isar to what many stakeholders viewed as a "wild-flowing mountain river" [75]. In conclusion, the Isar-Plan project illustrates an innovative approach to combining separate but synergistic agendas for fulfilling economic, social, and ecological priorities. It illustrates a process that internalized a paradigm shift in flood protection away from a sole reliance on grey structural measures to encompass a broad vision of the river for recreation and ecological aims. In the words of an Isar-Plan journalist and author:

I think the most important aspect was that the responsible actors realized that there is a new form of flood protection, which also consists of restoring nature (Interviewee \#13).

\subsubsection{Wolong Case}

Interviews on the Wolong experience exhibit three interrelated views or narratives on the benefits of China's National Forest Conservation Program (NFCP): flood and landslide protection, conservation, and economic wellbeing. NFCP's effect on improving the reduction of landslide and downstream flood risk by improving soil conservation was largely acknowledged by local communities [76] and interviewees. More pronounced were the perceived benefits of nature conservation. It was generally agreed by the interviewees that the NFCP played a pivotal role in reverting deforestation in the Wolong Nature Reserve (WNR), resulting in substantial gain in forests and their ecosystems in a mere seven years. Another widely acknowledged benefit is the NFPC's impact on the local economy and community wellbeing by enhancing the ecological infrastructure necessary for developing nature-based tourism [77].

Table 3 summarizes the governance factors that enabled the realization of the NFCP at the WNR as identified by 11 interviewees. The enablers are presented in two temporal phases: those factors or conditions that were in place before the project was initiated in 1999 (preconditions) and those that enabled or facilitated the initiation, planning, and implementation of the program.

From the multiple preconditions shown in Table 3, several can be selected as key in paving the road towards the realization of the conservation program. First, the NFCP was catapulted onto the national government's policy agenda by a catastrophic eventextensive floods in summer 1998-which opened a window of opportunity for government officials to advocate for the acceleration of a forestry sector reform and related conservation and restoration programs with unmatched political and financial resources. The renown of Wolong as the "Home of Giant Pandas" engendered strong political support for NFCP, as was symbolized by the visit of Prime Minister Rongji Zhu during its initiation. The publication of an article on the reserve's ecological issues in the prestigious Science magazine during the implementation of NFCP [78] further focused international and national attention on Wolong. Pressure groups such as WWF, and later, other international and domestic groups, through their continuous collaboration and interactions, planted seeds of innovative NBS governance ideas in the WNR system, or at least triggered some to think of alternatives for DRR [79]. 
Table 3. Enablers of the Wolong case in the view of the interviewed stakeholders.

Enablers as Preconditions

Enablers during Initiation, Planning, Design, and Implementation

Socio-cultura

Shared social norms local households

Recurrent local disaster events since the late 1980s, resulting, e.g., in relocation of a whole hamlet due to landslide risk, further exacerbated existing conflicts between conservation and development in WNR

\begin{tabular}{|c|c|c|c|}
\hline Interest/pressure group & $\begin{array}{l}\text { There was an integrated Conservation and Development Program (ICDP) and } \\
\text { science-based planning advocacy by international NGOs }\end{array}$ & Stakeholder engagement & There was an unprecedented consultation with local hamlets/communities \\
\hline $\begin{array}{l}\text { Risk awareness raised by } \\
\text { extreme events }\end{array}$ & $\begin{array}{c}\text { Massive disasters in the 1990s triggered the introduction of national and } \\
\text { regional NBS and DRR policies }\end{array}$ & & \\
\hline \multicolumn{4}{|l|}{$\begin{array}{l}\text { Legal/institutional/ } \\
\text { political }\end{array}$} \\
\hline Public property rights & $\begin{array}{l}\text { Since almost all forests in the WNR are government-owned, there were no } \\
\text { conflicts with private owners. }\end{array}$ & $\begin{array}{l}\text { Political pressure, will, } \\
\text { and support }\end{array}$ & $\begin{array}{c}\text { Visits of national leaders, especially Prime Minister Rongji Zhu to WNR in } \\
\text { 1999; international and national media attention on WNR following a Science } \\
\text { magazine article on ecological degradation in the WNR }\end{array}$ \\
\hline Mandate and authority & $\begin{array}{l}\text { The Wolong Special District Administrative Bureau, as the government body, } \\
\text { has obligation to protect communities from disaster risks }\end{array}$ & Local champion & $\begin{array}{l}\text { Two experienced government officials played pivotal roles in coordinating and } \\
\text { planning the NBS programs in the WNR }\end{array}$ \\
\hline Existing legal basis & $\begin{array}{l}\text { The first WNR Master Plan required NBS for synergies between DRR } \\
\text { and conservation }\end{array}$ & Cross-scale collaboration & $\begin{array}{l}\text { Collaboration across hierarchical levels within WNR, from reserve level, to } \\
\text { township, village, hamlets, and household groups designated specifically } \\
\text { for NFCP }\end{array}$ \\
\hline \multirow[t]{2}{*}{ Regional policy umbrella } & $\begin{array}{c}\text { There was an increased monitoring capacity and enforcement efforts on illegal } \\
\text { logging at the provincial level under NFCP }\end{array}$ & $\begin{array}{l}\text { Cross-sectoral } \\
\text { collaboration }\end{array}$ & $\begin{array}{l}\text { Strong collaboration across different departments within the government } \\
\text { systems, including the formation of the NFCP Planning and Coordination } \\
\text { Committee and the introduction of the Wolong Forest Police Squad }\end{array}$ \\
\hline & & $\begin{array}{l}\text { Innovative design of } \\
\text { incentive structure }\end{array}$ & $\begin{array}{l}\text { There was a shift from mainly "sticks" mechanisms to a novel combination of } \\
\text { "sticks and carrots" mechanisms }\end{array}$ \\
\hline $\begin{array}{l}\text { Expert knowledge and } \\
\text { expertise }\end{array}$ & $\begin{array}{l}\text { Rich knowledge on forests and the complexities of conservation-development } \\
\text { conflicts, and awareness of the effects of deforestation and forest degradation } \\
\text { on disaster risk }\end{array}$ & & \\
\hline \multicolumn{4}{|l|}{ Financial resources } \\
\hline Available funds & $\begin{array}{l}\text { Unprecedented financial resources from national NFCP fund were made } \\
\text { available, which was later renewed at increasing rates }\end{array}$ & $\begin{array}{l}\text { Additional funding } \\
\text { sources }\end{array}$ & Mixed sources ensured both the quantity and flexibility of funding \\
\hline
\end{tabular}


Turning to the post-initiation phase starting in 1999, the case interviews highlight a number of governance processes and institutional factors that helped pave the way for the NFCP. One important factor was Wolong's status as both a protected area and a special district with independent government functions and financial resources, which provided a unique level of flexibility in designing locally adaptive solutions. In Wolong, the DRR agenda was merged with the responsibilities of those administrative bodies with core interests in conservation and, to a lesser extent, tourism-related economic development. All interviewees acknowledged that the exceptional funding provided by the national government for the implementation, monitoring, and maintenance of the forestry program was essential. As a Department for the Natural Resources Management member noted:

Among all the factors, I would say that the financial capacity was the most important one. We had never had such level of funding, not mentioning that it was ensured for ten years and later further increased by almost one order of magnitude. Suddenly, a lot of what we wanted to do but could not do was possible. (Interviewee \#17).

The reserve's governing bodies and a wide range of administrative bodies at township and lower levels were coordinated by an innovative cross-departmental NFCP committee in the NBS initiation, planning, design, implementation, monitoring, and evaluation processes. This was supported by state-of-art technical expertise from research and practical partners. Indeed, the NBS vision shared by the national and local authorities can be viewed as an important driver of administrative innovation, spearheading the resulting polycentric governance arrangements that proved to be critically important in the realization of this ambitious NBS. As a member of the WNR Administrative Office noted:

Wolong, being also a special district, is unique in China's protected areas. We are not only a reserve, but also a government. While conservation and pandas are always of highest priority for us, we had no choice but to find solutions that may help us address development and disaster issues in synergy with conservation. (Interviewee \#21).

Another crucial, if not essential, enabler of the success in Wolong, again in the view of interviewees, was its innovative engagement of local communities with unprecedented consultation processes that resulted in the novel "carrot and stick" approach for forest protection. In an unprecedented engagement process, the local authorities designed and implemented monetary incentives for households in consultation with villagers for community-based monitoring of illegal logging. A local resident described the situation before the NFCP:

Before NFCP, I had never in my life seen so many high-level [reserve/county level] officials coming to my village and seriously talk with many families; neither in Xiaojin, nor in Wolong (...). We did not want to destroy our eco-environment, but the reserve put a lot of limitations on how we could use natural resources, without any compensation. With the NFCP, for the first time we were paid with cash for conservation work (Interviewee \#22).

This novel system in China complemented the traditional "sticks" approach for sanctioning illegal logging with "carrots" in the form of payments to household groups who were successful in preventing logging in their assigned forest areas. By following the "beneficiary pays" principle, the NFCP systems can be described as a payment for ecosystem services scheme [80]. Importantly, the recognition of past failed approaches for preventing illegal logging was an important driver of innovation. This sparked the adoption of a co-designed (national authorities with local authorities and citizens) approach for incentivizing forest protection. This system was, in turn, enabled by strong pre-existing social norms and trust within the communities that laid the ground for their mutual cooperation. In the words of a member of the Department of Natural Resources Management:

Many reserve managers and patrollers were born and grew up locally and had complex kindred relationships with local villagers, making it very hard for them to enforce punishment and confiscation when illegal logging happens, and sometimes they could also be bribed (... ). No one wanted to be the bad man and be hated by locals, espe- 
cially those who could barely survive with subsistence-based agriculture livelihoods.

(Interviewee \#18).

\subsubsection{Nocera Case}

The case of landslide prevention in Nocera Inferiore demonstrates how prior conditions and emerging governance factors can combine to play a synergistic role in enabling the realization of a landslide NBS in Italy. The recently constructed NBS in the form of a natural engineering work has been acclaimed as providing landslide protection and multiple accompanying co-benefits that include recreational value, equity in protecting the community, esthetic value, increased access to mountain areas, heightened risk/environmental awareness along with economic benefits. Table 4 lists the preconditions and enablers that facilitated the initiation, planning, and implementation of the landslide protection NBS as viewed by the interviewees.

The Nocera case highlights at least three key NBS enablers. First, widescale stakeholder opposition to grey measures by interest or pressure groups and expert communities catalyzed the local decision-making processes for the NBS adoption. The root causes of opposition to grey measures, like those implemented in the neighboring town of Sarno, could be found in their high building and maintenance costs, aesthetic and environmental impact, false sense of full protection, and private land expropriation. A member of the victim's committee noted:

Sarno gives the wrong illusion to the local population: that everything can be solved with technical solutions. Instead, the visual and environmental impact of the control works in Sarno is excessive (Interviewee \#40).

Driven especially by local environmental associations, policymakers were able to strengthen collective agency and foster NBS transition initiatives. This movement depended on a small circle of associations that acted as agents of change and by speaking the language of multiple sectors could identify and support synergies among them. In the words of a staff member of the municipal technical office:

Waste management, urban development and risk reduction are all part of a broad environmental agenda. This also reflects the environmental awareness which changed over time. Thanks to a coalition of local politicians, officers and consultants, we have been able to push forward a new environmental agenda (Interviewee \#27).

Second, wide stakeholder engagement and local networks engaged in DRR, especially at municipal level, were key elements of governance innovation. Starting in 2010, an externally led, three-year participatory process involving affected and interested residents led to the identification of a compromise solution between NBS and grey measures as part of a co-designed landslide risk mitigation plan $[37,63]$. The process included extensive stakeholder interviews, a survey, public meetings, an interactive web platform, and an extended citizen deliberative process. Geotechnical engineers from the University of Salerno and the local municipal authorities provided three technical mitigation option packages, each within a given budget constraint and complying with Italian law, and each supporting a different vision or worldview for landslide protection. The Emergency Commissioner, who took office after the 2005 landslide events, voiced the value of shared responsibility for the decision:

I can definitely benefit from the results of the participatory process because they helped me to better understand what residents think, and I can share the responsibility for the decision with the participants (Interviewee \#44). 
Table 4. Enablers of the Nocera case in the view of the interviewed stakeholders.

\begin{tabular}{|c|c|c|c|}
\hline \multicolumn{2}{|r|}{ Enablers as Preconditions } & \multicolumn{2}{|c|}{ Enablers during Initiation, Planning, Design, and Implementation } \\
\hline Socio-cultural & & & \\
\hline $\begin{array}{l}\text { Opposition to grey } \\
\text { measures }\end{array}$ & $\begin{array}{l}\text { High costs and visual and environmental impacts were root } \\
\text { causes of opposition to grey measures and of support for NBS }\end{array}$ & Interest groups/coalitions & $\begin{array}{l}\text { Environmental, social associations, and landslide victims } \\
\text { committee continued to act as agents of change }\end{array}$ \\
\hline Interest groups/coalitions & $\begin{array}{l}\text { Environmental, social associations, and landslide victims } \\
\text { committee were acting as agents of change }\end{array}$ & & \\
\hline Environmental awareness & $\begin{array}{c}\text { There was a general change in social norms, more attention } \\
\text { dedicated to environmental issues }\end{array}$ & & \\
\hline $\begin{array}{l}\text { Risk awareness raised by } \\
\text { extreme events }\end{array}$ & $\begin{array}{l}\text { Landslide risk became an important topic for the residents, } \\
\text { especially after the } 2005 \text { event }\end{array}$ & & \\
\hline \multicolumn{4}{|l|}{$\begin{array}{l}\text { Legal/institutional/ } \\
\text { political }\end{array}$} \\
\hline $\begin{array}{l}\text { Opposition to decision } \\
\text { made at regional level }\end{array}$ & $\begin{array}{l}\text { Stakeholders at municipal level opposed to decisions of regional } \\
\text { agencies for the first time (year 2008) }\end{array}$ & $\begin{array}{l}\text { Opposition to decision made at } \\
\text { regional level }\end{array}$ & $\begin{array}{l}\text { Stakeholders at municipal level opposed to decisions of } \\
\text { regional agencies for the second time (year 2016) }\end{array}$ \\
\hline \multirow[t]{3}{*}{ Cross-sectoral collaboration } & $\begin{array}{l}\text { Waste management, urban development, and risk mitigation } \\
\text { were all included in the same "environmental agenda" }\end{array}$ & $\begin{array}{l}\text { Political will and } \\
\text { support/champions }\end{array}$ & $\begin{array}{l}\text { Local politicians, the mayor, and environmental councilor } \\
\text { were in favor of NBS }\end{array}$ \\
\hline & & Mandate and authority & $\begin{array}{l}\text { The municipal technical office had a mandate to } \\
\text { implement NBS }\end{array}$ \\
\hline & & Trust relationship & $\begin{array}{l}\text { A trust relationship was built between coalitions at } \\
\text { local/municipal level }\end{array}$ \\
\hline \multicolumn{4}{|l|}{ Human resources } \\
\hline \multirow[t]{2}{*}{$\begin{array}{l}\text { Expert knowledge and } \\
\text { expertise }\end{array}$} & $\begin{array}{c}\text { New and robust scientific evidence was presented to } \\
\text { support NBS }\end{array}$ & Expert knowledge and expertise & Scientific evidence continued to support NBS \\
\hline & & Co-design of risk mitigation plan & $\begin{array}{l}\text { The co-design between experts and stakeholders allowed a } \\
\text { compromise solution for risk mitigation to be found }\end{array}$ \\
\hline \multicolumn{4}{|l|}{ Financial resources } \\
\hline Available funds & $\begin{array}{l}\text { EUR } 7 \text { million regional funding made available for } \\
\text { risk mitigation }\end{array}$ & Limited funds & The proposed NBS were less expensive than grey measures \\
\hline
\end{tabular}


By bringing together residents and experts to co-produce risk management options, the process reached a compromise solution for landslide risk mitigation that mediated not only different interests but also strongly conflicting worldviews. The plan included the NBS implemented in 2019. The process was described by a local environmental NGO:

I believe that the [stakeholder engagement] process strongly influenced the administrative dynamics of landslide risk mitigation in Nocera Inferiore. It catalyzed the construction of natural engineering works and had very positive effects on the community. We should continue working in the same way (Interviewee \#38).

Third, the limited funding availability paradoxically enabled the choice of the NBS option (with lower maintenance costs) over a more costly structural grey solution. However, not only economic but also environmental, risk reduction, and social benefits played a critical role in the NBS choice.

In sum, this case demonstrates how prior conditions, especially the widescale opposition to grey landslide measures, together with emergent governance factors including the web of change agents and the inclusive stakeholder process, led to the realization of a nature-based solution in Nocera Inferiore. Most notable is the innovative and pioneering stakeholder co-production process, itself driven by the opposition to grey measures and willingness on the part of the municipality to engage residents and experts in the design of the infrastructure investment.

\section{Discussion}

The diversity of the case studies along political, socioeconomic, and ecological dimensions, as well as the small sample of three cases, precludes generalizable comparisons in terms of the prioritization and effectiveness of governance enablers. With this in mind, we draw attention to similarities and differences in the governance conditions and factors with the aim of providing exemplary, but not generalizable, insights that have been acknowledged by stakeholder citations.

\subsection{Preconditions}

The interviews displayed notable similarities and also important differences in the governance preconditions that were to prove valuable for the realization of NBS in each case. Perhaps the most reported precondition was the availability of funds (noting that, in the Nocera case, the limited funds precluded the need for costly grey measures). In each case, the financing was in place (or promised) at the initiation of the NBS policy process. Given available financing for landslide or flood risk reduction, the governance system shaped the final hybrid or nature-based outcome that, in all cases, encompassed broader societal aims. For this, a mandate and favorable legal conditions (such as public property ownership) played a pivotal role. Additionally, as recognized by Trinomics \& IUCN [81], despite the wealth of existing funding mechanisms, NBS projects are primarily either directly financed by public authorities, as was the case for Isar and Nocera, or by authorities encouraging and incentivizing other actors (e.g., residents) to contribute to maintaining NBS in the public domain, as was the case for Wolong. Pre-existing interest and pressure groups combined with opposition to grey infrastructure measures appeared to be critical for the NBS to emerge on political agendas in the Isar and Nocera cases. In the Wolong and Nocera cases, a flood/landslide event at or near the case site, or (in the Isar case) a model which simulated a catastrophic event, opened a window of opportunity for already existing environmental groups or sympathetic state authorities, along with expert communities, to advocate for a nature-based or hybrid solution. This is consistent with empirical investigations showing that a major event can result in policy change if groups or coalitions advocating for the policy change are already in place [82].

Not surprisingly, the Chinese system differs across many governance preconditions compared with the European systems, most notably in the absence of pre-existing interest and pressure groups, although the Chinese authorities recognized the importance of consulting with households that would be affected by the new monitoring and financing 
scheme. Moreover, many differences can be explained by the distinction between flood and landslide hazards, which require different types of disaster management and emergency responses.

\subsection{Enablers from Project Initiation to Completion}

The enabling factors that emerged during the NBS policy process built on the commonalities exhibited by the preconditions (Section 4.1). In the Nocera and Isar cases, for example, interest and pressure groups together with expert communities existed before the project was initiated, yet they continued (in a different or strengthened form) to be a main driving force for an NBS. In the Isar case, the advocacy emerged both from within the administration as well as from civil society, both with vocal and charismatic individual champions. Thus, in all cases, strong interest groups in and outside the administrative bodies, along with their individual champions, appeared to be a key enabler for realizing the NBS.

Results also show commonalities in collaboration among the authorities. The multiscale (Isar and Wolong) and cross-sectoral (Nocera and Isar) collaboration (two characteristics of polycentric governance) broke administrative silos that are typical in public administrations. This finding is consistent with Bernardi et al. [28], who identify policies to support collaboration and synergies of policymaking at diverse scales as major NBS drivers. Ingold et al. [83] also highlight the importance of actor embeddedness in "vertical" and "horizontal" governance structures for disaster risk management in mountain regions. As reflected in her design principles, Ostrom [71] championed the importance of the polycentric governance model in providing public goods. In contrast to more monocentric processes, polycentric governance provides opportunities for learning and experimentation and enables broader levels of participation [71].

A similar polycentric arrangement emerged in the Wolong case. Analogous to the Isar working group, a cross-department NFCP committee emerged, which was led by two governmental champions with rich local knowledge and bridged across separate disaster protection-conservation-development agendas. In the case of Nocera Inferiore, members of the pressure groups, some of whom were also members of the local municipal council, often acted as mediators, translators, and networkers among different levels of government and different sectors/domains. Thus, in each of the NBS cases, it appears that novel administrative collaboration across sectors and scales was instrumental in enabling the realization of the NBS.

Although there were no formal procedures (such as environmental impact assessments) for involving civil society, businesses, and other stakeholders in the process, stakeholder engagement was a central feature of each case. This is in line with Schmalzbauer et al. [25] and Fohlmeister et al. [84], who identify citizen involvement, social inclusion, and public acceptance as key NBS enablers. However, the engagement of stakeholders took different forms. In the Isar case, an ad hoc yet inclusive participatory process emerged that shaped the outcome toward an NBS; in Nocera, a unique process was designed and carried out that coupled resident stakeholders and experts in the co-design of alternative and competing landslide mitigation options, including NBS, and facilitated a compromise that influenced the broader contentious policy process. In the Wolong case, in an almost unprecedented move, public officials consulted village leaders and households on the form of the newly designed incentive system for preventing illegal logging. In "town hall" meetings across the nature reserve, the authorities achieved a broad consensus for their "carrot and stick" reforms, and, beyond consensus, they reshaped the scheme based on villager input.

Noticeably, the trust, common vision, and clear goals so often mentioned by interviewees in the Isar case are absent (for different reasons) in the Nocera and Wolong cases. In the Isar case, the differing goals of flood protection, ecological wilderness, and recreation could all be accommodated to a large extent by the Isar-Plan hybrid, and the available budget 
could accommodate the investments. Indeed, the natural measures were "piggy-backed" on a grey solution. Thus, the interviewees spoke of a common vision and common goals.

In the Nocera case, different views on priorities for landslide risk continue to be present; thus, a common vision and goals have rarely been mentioned by interviewees. In the Wolong case, the government and communities shared the vision of maintaining a healthy forest ecosystem, although the common vision did not appear to be a main driver for the NBS, as stakeholders reported a lack of trust between local communities and government before NFCP. Within communities, cooperation and trust play an important role in the design of the group monitoring, and the successful implementation of NFCP helped to stem the further attrition of trust between government and communities, if not substantially restoring it.

The enablers derived from the three cases' interviews were non-specific to mountain areas and are thus (to some extent) transferable to other environmental settings. Contrastingly, many of the highlighted key enablers were specific to a DRR context. This suggests that NBS' main purpose and scope are more important for their enabling of governance processes than their geographic setting or habitat type.

\subsection{Limitations and Research Gaps}

While the three NBS cases are illustrative of innovative policy practices, institutional capabilities, organizational processes, and social relations in their respective unique socioeconomic settings, it should be noted that "innovation" and "success" remain difficult to assess, subjective, and context-specific depending on "for whom", "of what", and "for what purpose". A limitation of the analysis is that by focusing on only three disparate cases, results cannot be universally generalized to different political systems and socioeconomic contexts. We do, however, provide analytical conclusions and insights across cases, which can contribute to and help build the current knowledge base on NBS governance.

The purpose of the study is thus not to identify deficits or best practices across governance processes operating in different settings, but rather to provide an overview of the governance conditions and factors that enabled their realization according to interviewed stakeholders. Since interviewees were not asked to rank enablers, the results provide an overview of the constellation of governance factors that came together to enable the NBS in each case, yet they do not provide any order of prioritization or differentiation on which enablers were sufficient and which were indispensable prerequisites for the final NBS.

Moreover, the case studies report on the policy processes after funding had been secured. Thus, they are limited to addressing administrative (not political) governance as they do not encompass the typically politicized decisions on resource and budget allocations. Despite being a critical aspect of governance, case studies of NBS financing and financial innovation in Europe are sparse, mainly because most NBS (as in our cases) are publicly funded [85-87]. Further research is thus needed on both the enablers of public funding for NBS and innovative business and other financing options, such as payments for ecosystem services.

Despite the growing body of literature on NBS enablers and barriers (e.g., $[5,23,25,27-29])$, further research is still needed to guide decision-makers and practitioners on NBS realization, both from a technical perspective and governance perspective. This includes identifying relevant policy mechanisms, along with levers for institutional reform, that can better enable NBS implementation and upscaling. Additionally, we recognize that such guidance will need to be adapted to different contexts (e.g., covering rural areas as well as urban settings) and scales (e.g., regional, national, and international scales). Finally, the case study results are interesting for what they do not show-namely, the absence of formal assessments or available guidelines for the NBS (identified as an important NBS driver [28]). Despite the scale of the NBS projects (Isar-Plan (EUR 35 million), Nocera Inferiore (EUR 637,000), and Wolong (approx. EUR 20 million to date)), there were no formal assessments at the site scale of the cost-effectiveness of the NBS in reducing flood and landslide risks, nor any quantitative assessments of the co-benefits in 
terms of biodiversity, climate adaptation, recreation, and other human wellbeing indices. Furthermore, there was little involvement of private businesses or private funds in the policy procedures and outcomes.

\section{Conclusions}

While the realization of NBS is nested in complex political and socioeconomic settings, this study represents a first attempt at distilling the governance factors that contributed to the realization of NBS. In each of the three cases, interviews confirmed the benefits of the NBS and, importantly, the co-benefits that reached beyond their main aim of reducing flood and landslide risk and that added significantly to the NBS rationale, appeal, and eventual adoption. In particular, cultural, social, and recreational co-benefits were highlighted by interviewees.

A major insight to emerge from the case studies is thus the importance of merging the disaster risk reduction, ecological, climate adaptation, and human welfare agendas. This insight underlines the importance of NBS in contributing to global sustainability as expressed in the UN Sustainable Development Goals (SDGs), the Sendai Framework on disaster risk reduction (2015), the Paris Agreement (2016) on climate change, the Global Commission on Adaptation (2019), and post-2020 biodiversity agreements (e.g., European Commission, 2020). As shown in the case studies, the fulfillment of multiple agendas can be furthered by focusing strongly on NBS as a complement, even in some cases an alternative, to conventional structural (grey) infrastructure for reducing disaster risk. By integrating transformative global agendas, the transition to NBS, as shown here and elsewhere, is not only viable but necessary and urgent.

The three cases underline crucial preconditions for the development of an NBS agenda, such as a legal mandate and favorable political constellation, fueled by the criticisms of a grey structural model or (in Wolong) of a failed enforcement regime. Furthermore, a catastrophic event (or a model predicting one) appeared key for opening a window of opportunity for existing pressure groups or sympathetic state authorities. Perhaps the most indispensable precondition was the existence of earmarked budgets or availability of funds, without which an NBS could not have been envisaged.

The cases also illustrate the potential of NBS to drive innovative governance arrangements. This was highlighted by the novel working groups and other emerging constellations for cross-scale and cross-sector collaboration. The mainstreaming of NBS into policy agendas, as the three cases illustrate, can be facilitated with polycentric arrangements in public administration that cut across administrative bodies. For example, authorities responsible for flood/landslide risks and for water, urban planning, nature reserves, and waste management collaborated to realize the NBS. Another innovative governance enabler driven by the quest for an NBS was the novel and pioneering arrangements for stakeholder engagement, which included co-generation of the NBS design in the Nocera and Isar cases and consultation on the enforcement regime in the Wolong case. In Europe, stakeholder participation was complemented by coalition advocacy groups and their champions. The cases also provide evidence of what many consider the near inevitability of hybrid NBS solutions. Governance involves finding compromises that can resolve the interest and value conflicts often underlying the transition from traditional infrastructure to NBS.

The selected case studies hence provide lessons that extend far beyond Munich, Nocera Inferiore, and Wolong. They show how NBS can contribute to the urgent transformations needed to meet global goals and targets. As the cases have demonstrated, the synergies in disaster protection, climate mitigation and adaptation, biodiversity, and human welfare can be exploited with a concerted and inclusive effort that embraces a transition to NBS.

Supplementary Materials: The project deliverable report on which this study was based is available at: https:/ / phusicos.eu/wp-content/uploads/2020/10/D5_1_NBS-in-depth-case-study-analysis_ Final.pdf. 
Author Contributions: Conceptualization, J.G.C.M., A.S. and J.L.-B.; methodology, J.G.C.M.; validation, J.G.C.M.; formal analysis, J.G.C.M., A.S. and W.L.; investigation, J.G.C.M., A.S. and W.L.; data curation, J.G.C.M., A.S. and W.L.; writing—original draft preparation, J.G.C.M.; writing-review and editing, A.S., J.L.-B.,W.L. and J.B.; visualization, J.G.C.M.; supervision, J.L.-B.; project administration, J.L-B.; funding acquisition, J.L.-B. All authors have read and agreed to the published version of the manuscript.

Funding: This research was funded by the European Community's Seventh Framework Programme through the grant to the budget of the PHUSICOS Project (https:/ / phusicos.eu/) (EU H2020 research and innovation programme grant agreement No. 776681).

Institutional Review Board Statement: Not applicable.

Informed Consent Statement: Informed consent was obtained from all subjects involved in the study.

Data Availability Statement: Data sharing is not applicable to this article.

Acknowledgments: This work reflects the authors' views and not those of the European Community. Neither the European Community nor any member of the PHUSICOS Consortium is liable for any use of the information in this study. We wish to thank all the colleagues, including all PHUSICOS partners, and persons who provided us with professional advice and collaboration. We would like to express our gratitude to Farrokh Nadim and Amy Oen (Norwegian Geotechnical Institute), Brian Faith (International Institute for Applied Systems Analysis), Aude Zingraff-Hamed and Gerd Lupp (Technical University Munich) for their quality control and support in improving the background report for this paper. For the Nocera case, we are especially grateful to some local partners including: Luca Pucci (Leonia Legambiente Campania), Settimio Ferlisi and Leonardo Cascini (University of Salerno), Sergio Falcone (Retired Technical Office of Nocera Inferiore). For the Isar case study, we would like to thank members of the Munich Forum, Isar Valley Association, Munich Water Agency, Fisheries Association, Canoeing Association, Save the Isar Now, Munich City Utilities, the group Burkhardt I Engelmayer, and Isar Alliance in particular. Last but not least, we thank the 47 interviewees of the three case studies, who devoted their precious time to our interviews and meetings. Without them, our research work would not have been possible.

Conflicts of Interest: The authors declare no conflict of interest. The funders had no role in the design of the study; in the collection, analyses, or interpretation of data; in the writing of the manuscript, or in the decision to publish the results.

\section{Appendix A. Interview Protocol}

Interviewer Name:

Interviewee Name:

Employer, Department:

Position:

\section{A. Introduction and Background}

1. Please briefly describe your role in your organization/work place?

2. When and how were you involved with the [NBS project]?

\section{B. Success factors and enablers}

3. In your opinion, why was the [NBS project] needed when it was implemented? What was the main issue?

4. At that time, what were the other proposed solutions and their advocates?

5. In your opinion, what was the one most important driver in implementing the [NBS project]?

6. In your opinion, what was the single most important factor in the process of the [NBS project]?

7. What do you think is the main achievement of the [NBS project]?

8. On the flipside, what do you think its biggest shortcoming is? In hindsight, what would you do differently?

9. In your opinion, has the [NBS project] been used as a model of good practice?

10. Do you think the costs of the [NBS project] were split in a fair way? 


\section{Stakeholders of the NBS case}

11. How were stakeholders involved in the decision-making process?

12. Who were the strongest advocates? Was there a champion? Who opposed the plan?

13. Where did your organization get its information from when needed?

D. Concluding the interview

14. Would you be happy to be contacted by us if we needed any further information or clarification?

15. Is there any other person that you think would be useful for us to contact in the context of our research?

\section{E. Additional questions (time permitting)}

16. Were ecosystem services a concept you came across during your work on the [NBS project]? If you know about it, do you think it is a useful concept?

17. Was there funding for maintenance and monitoring of the project? Where does it come from?

F. Demographics

Age group: 18-24 years old; 25-34 years old; 35-44 years old; 45-54 years old; 55-64 years old; 65-74 years old; 75 years or older

Background: Ecology; Economics; Engineering; Environmental Sciences; Social Sciences, Political Sciences; other

Highest academic grade: A-levels; Bachelor; Master; PhD; other

Gender: F/M

Appendix B. Interviewee List and Interview Details

\begin{tabular}{|c|c|c|c|c|c|}
\hline $\begin{array}{l}\text { Interviewee } \\
\text { Number }\end{array}$ & $\begin{array}{l}\text { Case Study } \\
\text { Site }\end{array}$ & Organization or Affiliation & $\begin{array}{l}\text { Interview } \\
\text { Method }\end{array}$ & Date of Interview & Interviewer \\
\hline 1 & Isar case & City of Munich Planning Division & Face-to-face & 18 March 2019 & J.M. \\
\hline 2 & Isar case & Munich Water Agency & Face-to-face & 19March 2019 & J.M. \\
\hline 3 & Isar case & $\begin{array}{c}\text { Burkhardt Engelmayer Landscape } \\
\text { Architects }\end{array}$ & Face-to-face & 19 March 2019 & J.M. \\
\hline 4 & Isar case & Isar Alliance/Mühltal initiative & Face-to-face & 20 March 2019 & J.M. \\
\hline 5 & Isar case & Münchner Forum & Face-to-face & 20 March 2019 & J.M. \\
\hline 6 & Isar case & $\begin{array}{l}\text { NGO Save the Isar now!/Isar } \\
\text { Alliance }\end{array}$ & Written & 10 April 2019 & J.M. \\
\hline 7 & Isar case & Canoe Association/Isar Alliance & Telephone & 04 April 2019 & J.M. \\
\hline 8 & Isar case & City of Munich Construction Division & Telephone & 22 August 2019 & J.M. \\
\hline 9 & Isar case & Bavarian Fisheries Association & Telephone & 26 June 2019 & J.M. \\
\hline 10 & Isar case & $\begin{array}{c}\text { Bavarian Ministry of the } \\
\text { Environment }\end{array}$ & Telephone & 11 July 2020 & J.M. \\
\hline 11 & Isar case & Isar Alliance & Written & 08 August 2019 & J.M. \\
\hline 12 & Isar case & Isar Valley Association & Telephone & 01 August 2019 & J.M. \\
\hline 13 & Isar case & Journalist and author & Telephone & 08 August 2019 & J.M. \\
\hline 14 & Isar case & Technical University of Munich & Telephone & 01 March 2019 & J.M. \\
\hline 15 & Isar case & Munich City Utilities & Telephone & 28 August 2019 & J.M. \\
\hline 16 & Wolong case & $\begin{array}{c}\text { Wolong Nature Reserve } \\
\text { Administrative Bureau Deputy }\end{array}$ & Telephone & 19 July 2019 & W.L. \\
\hline 17 & Wolong case & $\begin{array}{c}\text { Department of Natural Resources } \\
\text { Management }\end{array}$ & Telephone & 18 July 2019 & W.L. \\
\hline
\end{tabular}




\begin{tabular}{|c|c|c|c|c|c|}
\hline 18 & Wolong case & $\begin{array}{c}\text { Department of Natural Resources } \\
\text { Management }\end{array}$ & Telephone & 19 July 2019 & W.L. \\
\hline 19 & Wolong case & $\begin{array}{c}\text { Department of Economic } \\
\text { Development }\end{array}$ & Telephone & 18 July 2019 & W.L. \\
\hline 20 & Wolong case & Department of Social Development & Telephone & 15 September 2019 & W.L. \\
\hline 21 & Wolong case & Administrative Office & Telephone & 15 September 2019 & W.L. \\
\hline 22 & Wolong case & Wolong township local resident & Telephone & 20 July 2019 & W.L. \\
\hline 23 & Wolong case & Wolong township local resident & Telephone & 20 July 2019 & W.L. \\
\hline 24 & Wolong case & $\begin{array}{c}\text { China Conservation and Research } \\
\text { Center for the Giant Panda }\end{array}$ & Telephone & 20 July 2019 & W.L. \\
\hline 25 & Wolong case & Peking University & Telephone & 20 September 2019 & W.L. \\
\hline 26 & Wolong case & Michigan State University & Telephone & 20 September 2019 & W.L. \\
\hline 27 & Nocera case & Municipal technical office & Telephone & April-September 2019 & A.S. \\
\hline 28 & Nocera case & $\begin{array}{l}\text { River Basin Authority (Autorità di } \\
\text { Bacino Distrettuale Appennino } \\
\text { Settentrionale) }\end{array}$ & Telephone & April-September 2019 & A.S. \\
\hline 29 & Nocera case & $\begin{array}{c}\text { Regional Coastal Ecosystem \& Water } \\
\text { Cycle Management Authority }\end{array}$ & Telephone & April-September 2019 & A.S. \\
\hline 30 & Nocera case & $\begin{array}{c}\text { International Center on } \\
\text { Environmental Monitoring }\end{array}$ & Telephone & April-September 2019 & A.S. \\
\hline 31 & Nocera case & University of Salerno & Telephone & April-September 2019 & A.S. \\
\hline 32 & Nocera case & Municipal Civil Protection & Telephone & April-September 2019 & A.S. \\
\hline 33 & Nocera case & Municipal Urban Planning Office & Telephone & April-September 2019 & A.S. \\
\hline 34 & Nocera case & $\begin{array}{c}\text { Regional Sustainable Education and } \\
\text { Citizen Participation Office }\end{array}$ & Telephone & April-September 2019 & A.S. \\
\hline 35 & Nocera case & Regional Environmental Agency & Telephone & April-September 2019 & A.S. \\
\hline 36 & Nocera case & National Civil Protection & Telephone & April-September 2019 & A.S. \\
\hline 37 & Nocera case & $\begin{array}{c}\text { Environmental NGO (Montagna } \\
\text { Amica) }\end{array}$ & Telephone & April-September 2019 & A.S. \\
\hline 38 & Nocera case & $\begin{array}{c}\text { Environmental NGO (Leonia) and } \\
\text { municipal council }\end{array}$ & Telephone & April-September 2019 & A.S. \\
\hline 39 & Nocera case & $\begin{array}{c}\text { Civil society, resident in landslide risk } \\
\text { area/participant in the process }\end{array}$ & Telephone & April-September 2019 & A.S. \\
\hline 40 & Nocera case & Victims' committee & Face-to-face & June 2010-October 2011 & A.S. \\
\hline 41 & Nocera case & Italian Environment Ministry & Face-to-face & June 2010-October 2011 & A.S. \\
\hline 42 & Nocera case & Regional Agency & Face-to-face & June 2010-October 2011 & A.S. \\
\hline 43 & Nocera case & $\begin{array}{c}\text { Participatory process scientific } \\
\text { advisor }\end{array}$ & Face-to-face & June 2010-October 2011 & A.S. \\
\hline 44 & Nocera case & Emergency Commission & Face-to-face & June 2010-October 2011 & A.S. \\
\hline 45 & Nocera case & $\begin{array}{l}\text { Civil society, farmer living on the } \\
\text { Mount Albino slope/participant in } \\
\text { the process }\end{array}$ & Face-to-face & June 2010-October 2011 & A.S. \\
\hline 46 & Nocera case & $\begin{array}{c}\text { Centre for GeoTechnologies, } \\
\text { University of Siena }\end{array}$ & Telephone & April-September 2019 & A.S. \\
\hline 47 & Nocera case & Municipal technical office & Telephone & April-September 2019 & A.S. \\
\hline
\end{tabular}




\section{Appendix C. Example of a "Mindmap" Created to Identify Emergent Themes from Interview Transcripts}

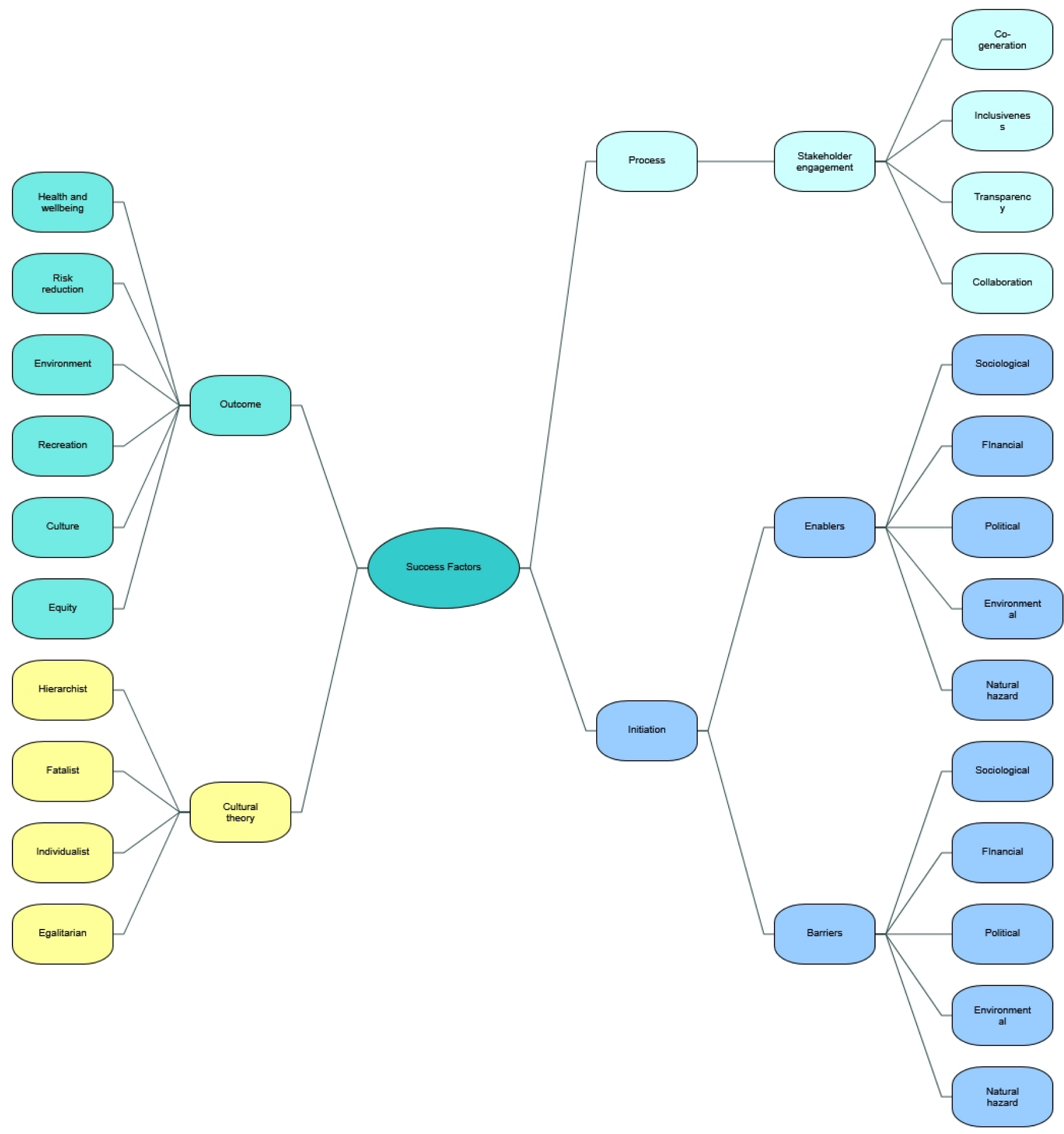

\section{References}

1. European Commission. Nature-Based Solutions. Available online: https://ec.europa.eu/info/research-and-innovation/researcharea/environment/nature-based-solutions_en (accessed on 2 December 2020).

2. Raymond, C.M.; Frantzeskaki, N.; Kabisch, N.; Berry, P.; Breil, M.; Nita, M.R.; Geneletti, D.; Calfapietra, C. A Framework for Assessing and Implementing the Co-Benefits of Nature-Based Solutions in Urban Areas. Environ. Sci. Policy 2017, 77, 15-24. [CrossRef] 
3. Davis, M.; Naumann, S. Making the Case for Sustainable Urban Drainage Systems as a Nature-Based Solution to Urban Flooding. In Nature-Based Solutions to Climate Change Adaptation in Urban Areas; Springer: Cham, Switzerland, 2017; pp. $123-137$.

4. Faivre, N.; Fritz, M.; Freitas, T.; de Boissezon, B.; Vandewoestijne, S. Nature-Based Solutions in the EU: Innovating with Nature to Address Social, Economic and Environmental Challenges. Environ. Res. 2017, 159, 509-518. [CrossRef] [PubMed]

5. Davies, C.; Lafortezza, R. Transitional Path to the Adoption of Nature-Based Solutions. Land Use Policy 2019, 80, 406-409. [CrossRef]

6. Ruangpan, L.; Vojinovic, Z.; Di Sabatino, S.; Leo, L.S.; Capobianco, V.; Oen, A.M.P.; McClain, M.E.; Lopez-Gunn, E. Nature-Based Solutions for Hydro-Meteorological Risk Reduction: A State-of-the-Art Review of the Research Area. Nat. Hazards Earth Syst. Sci. 2020, 20, 243-270. [CrossRef]

7. Seddon, N.; Daniels, E.; Davis, R.; Harris, R.; Hou-Jones, X.; Huq, S.; Kapos, V.; Mace, G.M.; Rizvi, A.R.; Reid, H. Global Recognition of the Importance of Nature-Based Solutions to Climate Change Impacts. Glob. Sustain. 2019, 3. [CrossRef]

8. Acharya, P.; Gupta, A.K.; Dhyani, S.; Karki, M. New Pathways for NbS to Realise and Achieve SDGs and Post 2015 Targets: Transformative Approaches in Resilience Building. In Nature-based Solutions for Resilient Ecosystems and Societies; Springer: Berlin/Heidelberg, Germany, 2020; pp. 435-455.

9. Accastello, C.; Blanc, S.; Brun, F.; Accastello, C.; Blanc, S.; Brun, F. A Framework for the Integration of Nature-Based Solutions into Environmental Risk Management Strategies. Sustainability 2019, 11, 489. [CrossRef]

10. Pfurtscheller, C.; Thieken, A.H. The Price of Safety: Costs for Mitigating and Coping with Alpine Hazards. Nat. Hazards Earth Syst. Sci. 2013, 13, 2619-2637. [CrossRef]

11. Zimmermann, M.; Keiler, M. International Frameworks for Disaster Risk Reduction: Useful Guidance for Sustainable Mountain Development? Mt. Res. Dev. 2015, 35, 195-202. [CrossRef]

12. United Nations Office for Disaster Risk Reduction (UNISDR). Sendai Framework for Disaster Risk Reduction 2015-2030; United Nations Office for Disaster Risk Reduction: Geneva, Switzerland, 2015.

13. Kabisch, N.; Frantzeskaki, N.; Pauleit, S.; Naumann, S.; Davis, M.; Artmann, M.; Haase, D.; Knapp, S.; Korn, H.; Stadler, J. Nature-Based Solutions to Climate Change Mitigation and Adaptation in Urban Areas: Perspectives on Indicators, Knowledge Gaps, Barriers, and Opportunities for Action. Ecol. Soc. 2016, 21, 1-15. [CrossRef]

14. Van der Jagt, A.P.N.; Szaraz, L.R.; Delshammar, T.; Cvejić, R.; Santos, A.; Goodness, J.; Buijs, A. Cultivating Nature-Based Solutions: The Governance of Communal Urban Gardens in the European Union. Environ. Res. 2017, 159, 264-275. [CrossRef]

15. Davis, M.; Abhold, K.; Mederake, L.; Knoblauch, D. Nature-Based Solutions in European and National Policy Frameworks. Deliverable 1.5, NATURVATION. Horizon 2020 Grant Agreement No 730243; European Commission: Brussels, Belgium, 2018 ; p. 15.

16. Ozment, S.; Ellison, G.; Jongman, B. Nature-Based Solutions for Disaster Risk Management: Booklet; World Bank Group: Washington, DC, USA, 2019.

17. Dorren, L.; Schwarz, M. Quantifying the Stabilizing Effect of Forests on Shallow Landslide-Prone Slopes. In Ecosystem-Based Disaster Risk Reduction and Adaptation in Practice; Springer: Berlin/Heidelberg, Germany, 2016; pp. 255-270.

18. Jackson, B.M.; Wheater, H.S.; McIntyre, N.R.; Chell, J.; Francis, O.J.; Frogbrook, Z.; Marshall, M.; Reynolds, B.; Solloway, I. The Impact of Upland Land Management on Flooding: Insights from a Multiscale Experimental and Modelling Programme. J. Flood Risk Manag. 2008, 1, 71-80. [CrossRef]

19. Rijke, J.; van Herk, S.; Zevenbergen, C.; Ashley, R. Room for the River: Delivering Integrated River Basin Management in the Netherlands. Int. J. River Basin Manag. 2012, 10, 369-382. [CrossRef]

20. Moos, C.; Bebi, P.; Schwarz, M.; Stoffel, M.; Sudmeier-Rieux, K.; Dorren, L. Ecosystem-Based Disaster Risk Reduction in Mountains. Earth-Sci. Rev. 2018, 177, 497-513. [CrossRef]

21. Calliari, E.; Staccione, A.; Mysiak, J. An Assessment Framework for Climate-Proof Nature-Based Solutions. Sci. Total Environ. 2019, 656, 691-700. [CrossRef]

22. Scolobig, A.; Martin, J.G.C.; Linnerooth-Bayer, J.; Balsiger, J.; Andrea, A.; Buckle, E.; Calliari, E.; Goltara, A.; Jurik, J.; Mink, F.; et al. Policy Innovation for Nature-Based Solutions in the Disaster Risk Reduction Sector Synthesis of the First Nature-Based Solutions Policy Business Forum Workshop; European Commission: Brussels, Belgium, 2020.

23. Sarabi, S.; Han, Q.; Romme, L.; Georges, A.; de Vries, B.; Wendling, L. Key Enablers of and Barriers to the Uptake and Implementation of Nature-Based Solutions in Urban Settings: A Review. Resources 2019, 8, 121. [CrossRef]

24. Somarakis, G.; Stagakis, S.; Chrysoulakis, N. Thinknature Nature-Based Solutions Handbook. ThinkNature Project Funded by the EU Horizon 2020 Research and Innovation Programme; European Commission: Brussels, Belgium, 2019.

25. Schmalzbauer, A. Barriers and Success Factors for Effectively Cocreating Nature-Based Solutions for Urban Regeneration. Deliverable 1.1.1, CLEVER Cities, H2020 Grant No. 776604; European Commission: Brussels, Belgium, 2018.

26. Kabisch, N.; Korn, H.; Stadler, J.; Bonn, A. Nature-Based Solutions to Climate Change Adaptation in Urban Areas; Springer: Berlin/Heidelberg, Germany, 2017. [CrossRef]

27. Kuban, B.; Demir, E.; Emir, K.; Tabanoğlu, O. D1.5: Barriers and Boundaries Identification; European Commission: Brussels, Belgium, 2018.

28. Bernardi, A.; Enzi, S.; Mesimäki, M.; Lehvävirta, S.; Jurik, J.; Kolokotsa, D.; Gobakis, K.; van Rompaey, S.G.E.; Mink, E.; Sansoglou, P.; et al. Barriers Landscape and Decision Making Hierarchy for the Sustainable Urbanisation in Cities via NBS (Deliverable 5.1) ThinkNature Project Funded by the EU Horizon 2020 Research and Innovation Programme under Grant Agreement No. 730338; European Commission: Brussels, Belgium, 2019. 
29. Frantzeskaki, N. Seven Lessons for Planning Nature-Based Solutions in Cities. Environ. Sci. Policy 2019, 93, 101-111. [CrossRef]

30. Sartori, R. Die Neue Isar: Renaturierung, Kulturelle Öffnung Und Ideen-Fluß, Geschichtliches Wie Literarisches/2. Band; Buch \& Media: Munich, Germany, 2011.

31. Sartori, R. Die Neue Isar: Renaturierung, Kulturelle Öffnung Und Ideen-Fluß, Geschichtliches Wie Literarisches/3. Band; Buch \& Media: Munich, Germany, 2012.

32. Ferrigno, N. Basta Colate Di Cemento i Canaloni Di Montalbino Rifatti Con i Muri a Secco. Il Mattino 2019, 30, 6.

33. Sartori, R. Die Neue Isar: Renaturierung, Kulturelle Öffnung Und Ideen-Fluß, Geschichtliches Wie Literarisches/1. Band; Buch \& Media: Munich, Germany, 2010.

34. Sartori, R. Die Neue Isar: Renaturierung, Kulturelle Öffnung Und Ideen-Fluß, Geschichtliches Wie Literarisches/4. Band; Buch \& Media: Munich, Germany, 2012.

35. Zingraff-Hamed, A.; Martin, J.C.G.; Lupp, G.; Linnerooth-Bayer, J.; Pauleit, S. Designing a Resilient Waterscape Using a Living Lab and Catalyzing Polycentric Governance. Landsc. Archit. Front. 2019, 3, 12-31.

36. Wamsler, C.; Pauleit, S.; Zölch, T.; Schetke, S.; Mascarenhas, A. Mainstreaming Nature-Based Solutions for Climate Change Adaptation in Urban Governance and Planning. In Nature-Based Solutions to Climate Change Adaptation in Urban Areas; Springer: Cham, Switzerland, 2017; pp. 257-273.

37. Scolobig, A.; Thompson, M.; Linnerooth-Bayer, J. Compromise Not Consensus: Designing a Participatory Process for Landslide Risk Mitigation. Nat. Hazards 2016, 81, 45-61. [CrossRef]

38. Liu, J.G.; Daily, G.C.; Ehrlich, P.R.; Luck, G.W. Effects of Household Dynamics on Resource Consumption and Biodiversity. Nature 2003, 421, 530-533. [CrossRef] [PubMed]

39. Song, Z.; Ouyang, Z.; Xu, W. The Role of Fairness Norms the Household-Based Natural Forest Conservation: The Case of Wolong, China. Ecol. Econ. 2012, 84, 164-171. [CrossRef]

40. Viña, A.; Chen, X.; McConnell, W.J.; Liu, W.; Xu, W.; Ouyang, Z.; Zhang, H.; Liu, J. Effects of Natural Disasters on Conservation Policies: The Case of the 2008 Wenchuan Earthquake, China. Ambio 2011, 40, 274-284. [CrossRef]

41. STEPS Centre. Innovation, Sustainability, Development; STEPS Centre: Brighton, UK, 2010.

42. Strout, J. PHUSICOS Deliverable D1.5: Innovation Management Plan; (in preparation). European Commission: Brussels, Belgium.

43. Albert, C.; Spangenberg, J.H.; Schröter, B. Nature-Based Solutions: Criteria. Nature 2017, 543, 315. [CrossRef]

44. Dorst, H.; van der Jagt, A.; Raven, R.; Runhaar, H. Urban Greening through Nature-Based Solutions - Key Characteristics of an Emerging Concept. Sustain. Cities Soc. 2019, 49, 101620. [CrossRef]

45. Naylor, L.A.; Kippen, H.; Coombes, M.A.; Horton, B.; MacArthur, M.; Jackson, N. Greening the Grey: A Framework for Integrated Green Grey Infrastructure (IGGI); University of Glasgow: Glasgow, UK, 2017.

46. Figure 1: The Grey-Green Continuum of Infrastructure Approaches. Sources: Mangrove by Ruliani, wall by Alya Nafisa, dunes by Daan, sea plant by Agne Alesiute, Seaweed by Vladimir Belochkin from the Noun Project; Design: Juliette C. G. Martin 2019.

47. Institute on Governance (IOG). What is governance? Available online: https: / / iog.ca/ what-is-governance (accessed on 22 November 2020).

48. Biermann, F.; Siebenhüner, B.; Schreyögg, A. International Organizations in Global Environmental Governance; Routledge: Abingdon, UK, 2009; Volume 17.

49. Figure 2: Enablers throughout the NBS Realization Stages. Sources: Icons by sahua d, Adrien Coquet and Line Icons Pro from the Noun Project, Design: Juliette C. G. Martin 2019.

50. Corbin, J.; Strauss, A.; Strauss, A.L. Basics of Qualitative Research; Sage: Thousands Oaks, CA, USA, 2015.

51. Raymond, C.M.; Breil, M.; Nita, M.R.; Kabisch, N.; de Bel, M.; Enzi, V.; Frantzeskaki, N.; Geneletti, G.; Lovinger, L.; Cardinaletti, M. An Impact Evaluation Framework to Support Planning and Evaluation of Nature-Based Solutions Projects. Report Prepared by the EKLIPSE Expert Working Group on Nature-Based Solutions to Promote Climate Resilience in Urban Areas; Centre for Ecology and Hydrology: Lancaster, UK, 2017.

52. Huthoff, F.; ten Brinke, W.; Schielen, R.; Daggenvoorde, R.; Wegman, C. Evaluating Nature-Based Solutions Best Practices, Frameworks and Guidelines; European Commission: Brussels, Belgium, 2018.

53. Autuori, S.; Caroppi, G.; De Paola, F.; Giugni, M.; Pugliese, F.; Stanganelli, M.; Urciuoli, G. Deliverable D4.1 Comprehensive Framework for NBS Assessment; European Commission: Brussels, Belgium, 2019.

54. National Science Foundation. CNH: Effects of Cross-Boundary Processes on Human-Nature Dynamics in Wolong Nature Reserve for Giant Pandas. Available online: https:/ / www.nsf.gov/awardsearch/showAward?AWD_ID=0709717 (accessed on 23 November 2020).

55. Norwegian Geotechnical Institute. R\&D Program: SafeLand. Available online: https://www.ngi.no/eng/Projects/SafeLand (accessed on 23 November 2020).

56. Yin, R.K. Case Study Research Design and Methods, 5th ed.; Sage: Thousand Oaks, CA, USA, 2014.

57. Bohm, O.; Wetzel, K.-F. Flood History of the Danube Tributaries Lech and Isar in the Alpine Foreland of Germany. Hydrol. Sci. J. 2006, 51, 784-798. [CrossRef]

58. Kropp, C. Einleitung: Natur Im Konflikt. In Natur; Springer: Berlin/Heidelberg, Germany, 2002; pp. 11-27.

59. Bäumler, K. Weltwassertag 2018: 200. Geburtstag Max von Pettenkofer; 125 Jahre Schwemm-Kanalisation in München; Münchner Forum: Munich, Germany, 2018; p. 2. Available online: https://muenchner-forum.de/wp-content/uploads/2018/03/Weltwassertag-20 18_Kanalfuehrung_MueFo_Historische_Informationen-.pdf (accessed on 9 January 2021). 
60. Wasserwirtschaftsamt München and Landeshauptstadt München. Isar-Plan: A New Lease of Life for the Isar River! Wasserwirtschaftsamt München and Landeshauptstadt München: Munich, Germany, 2011.

61. Rossano, F. Isar Plan: The Wild as the New Urban? Contour J. 2016, 1, 1-10.

62. Schaller, G.B.; Hu, J.; Pan, W.; Zhu, J. The Giant Pandas of Wolong; University of Chicago Press: Chicago, IL, USA, 1985.

63. Linnerooth-Bayer, J.; Scolobig, A.; Ferlisi, S.; Cascini, L.; Thompson, M. Expert Engagement in Participatory Processes: Translating Stakeholder Discourses into Policy Options. Nat. Hazards 2016, 81, 69-88. [CrossRef]

64. Josephs, L.I.; Humphries, A.T. Identifying Social Factors That Undermine Support for Nature-Based Coastal Management. J. Environ. Manag. 2018, 212, 32-38. [CrossRef]

65. Bäumler, K. Die Isar in München. Von Der “Pissrinne" Zum Lebendigen Fluss 1970-2011; Presentation given the 20th of March 2019, 2019.

66. Bayerische Staatskanzlei. Bayerisches Naturschutzgesetz (BayNatSchG) Vom 23. Februar 2011 (GVBl. S. 82, BayRS 791-1-U), Das Zuletzt Durch Gesetz v. 24. Juli 2019 (GVBl. S. 405) Und Durch § 1 Des Gesetzes Vom 24. Juli 2019 (GVBl. S. 408) Geändert Worden Ist; Bayerische Staatskanzlei: Munich, Germany, 2011.

67. Bayerische Staatskanzlei. Verfassung Des Freistaates Bayern in Der Fassung Der Bekanntmachung Vom 15. Dezember 1998 (GVBl. S. 991, 992, BayRS 100-1-I), Die Zuletzt Durch Gesetze Vom 11. November 2013 (GVBl. S. 638, 639, 640, 641, 642) Geändert Worden Ist; Bayerische Staatskanzlei: Munich, Germany, 1998.

68. Düchs, J. Wann Wird's an Der Isar Wieder Schön?: Die Renaturierung Der Isar in Munchen; Über Das Verständnis von Natur in Der Großstadt; Utzverlag GmbH: Munich, Germany, 2014; p. 96.

69. Zingraff-Hamed, A.; Hüesker, F.; Lupp, G.; Begg, C.; Huang, J.; Oen, A.; Vojinovic, Z.; Kuhlicke, C.; Pauleit, S. Stakeholder Mapping to Co-Create Nature-Based Solutions: Who Is on Board? Sustainability 2020, 12, 8625. [CrossRef]

70. Eggermont, H.; Balian, E.; Azevedo, J.M.N.; Beumer, V.; Brodin, T.; Claudet, J.; Fady, B.; Grube, M.; Keune, H.; Lamarque, P. Nature-Based Solutions: New Influence for Environmental Management and Research in Europe. GAIA-Ecol. Perspect. Sci. Soc. 2015, 24, 243-248. [CrossRef]

71. Ostrom, E. Coping with Tragedies of the Commons. Annu. Rev. Polit. Sci. 1999, 2, 493-535. [CrossRef]

72. Dietz, T.; Ostrom, E.; Stern, P.C. The Struggle to Govern the Commons. Science 2003, 302, 1907-1912. [CrossRef] [PubMed]

73. Marshall, G.R. Polycentricity and Adaptive Governance. In Proceedings of the 15th Biennial Global Conference of the International Association for the Study of the Commons, Edmonton, AB, Canada, 25-29 May 2015.

74. Pahl-Wostl, C.; Knieper, C. The Capacity of Water Governance to Deal with the Climate Change Adaptation Challenge: Using Fuzzy Set Qualitative Comparative Analysis to Distinguish between Polycentric, Fragmented and Centralized Regimes. Glob. Environ. Chang. 2014, 29, 139-154. [CrossRef]

75. Kangler, G.; Liebl-Schwindhammer, B.; Voigt, A. Fascinating Wild Rivers-Social Perception of Wild Rivers and Its Relevance for Nature Conservation and Landscape Planning. Anliegen Natur. 2014, 36, 66-73.

76. Yang, W.; Liu, W.; Viña, A.; Tuanmu, M.-N.; He, G.; Dietz, T.; Liu, J. Nonlinear Effects of Group Size on Collective Action and Resource Outcomes. Proc. Natl. Acad. Sci. USA 2013, 110, 10916-10921. [CrossRef] [PubMed]

77. Liu, W.; Liu, J. Patterns and Impacts of Tourism Development in A Coupled Human and Natural System. Ph.D. Thesis, Michigan State University, East Lansing, MI, USA, 2012.

78. Liu, J.; Linderman, M.; Ouyang, Z.; An, L.; Yang, J.; Zhang, H. Ecological Degradation in Protected Areas: The Case of Wolong Nature Reserve for Giant Pandas. Science 2001, 292, 98. [CrossRef]

79. Schaller, G.B. The Last Panda; University of Chicago Press: Chicago, IL, USA, 1994.

80. Chen, X.; Lupi, F.; He, G.; Liu, J. Linking Social Norms to Efficient Conservation Investment in Payments for Ecosystem Services. Proc. Natl. Acad. Sci. USA 2009, 106, 11812-11817. [CrossRef]

81. Trinomics; IUCN. Approaches to Financing Nature-Based Solutions in Cities. Working Document Prepared in the Framework of the Horizon 2020 Project GrowGreen; European Commission: Brussels, Belgium, 2019.

82. Scolobig, A.; Linnerooth-Bayer, J.; Pelling, M. Drivers of Transformative Change in the Italian Landslide Risk Policy. Int. J. Disaster Risk Reduct. 2014, 9, 124-136. [CrossRef]

83. Ingold, K.; Balsiger, J.; Hirschi, C. Climate Change in Mountain Regions: How Local Communities Adapt to Extreme Events. Local Environ. 2010, 15, 651-661. [CrossRef]

84. Fohlmeister, S.; Zingraff-Hamed, A.; Lupp, G.; Pauliet, S.; Scolobig, A.; Linnerooth-Bayer, J.; Liu, W.; Oen, A. Guiding Framezork for Tailored Living Lab Establishment and Concept and Demonstrator Case Study Sites, Deliverable 3.1 of the PHUSICOS Project, European Union H2020 Programme; ETH Zurich: Zurich, Switzerland, 2018.

85. Ecologic Institute. Urban Nature Atlas-Naturvation; Ecologic Institute: Berlin, Germany, 2018.

86. Martin, J.C.G.; Scolobig, A.; Linnerooth-Bayer, J.; Liu, W. NBS In-Depth Case Study Analysis of the Characteristics of Successful Governance Models, Deliverable 5.1., PHUSICOS. H2020 Grant Agreement No. 776681; European Commission: Brussels, Belgium, 2019.

87. Strout, J.M.; Oen, A.M.; Kalsnes, B.G.; Solheim, A.; Lupp, G.; Pugliese, F.; Bernardie, S. Innovation in NBS co-design and implementation. Sustainability 2021, 13, 986. [CrossRef] 